\title{
DESIGN, SYNTHESIS, AND CHARACTERIZATION OF SOME NOVEL 4-AMINOANTIPYRINE DERIVATIVES AND EVALUATION OF THEIR ACTIVITY AS ANALGESIC AGENTS
}

\author{
ABEER ESSA MOHAMMAD ${ }^{1}$, MUNTHER ABDULJALEEL MUHAMMAD-ALI ${ }^{1, *}$, \\ DHURGHAM QASIM SHAHEED ${ }^{2}$, and BASIM JASIM HAMEED ${ }^{3}$
}

\author{
${ }^{1}$ Pharmaceutical Chemistry Department, College of Pharmacy, University of Basrah, Basrah, Iraq \\ ${ }^{2}$ College of Pharmacy, University of Alkafeel, Najaf, Iraq \\ ${ }^{3}$ Department of Laboratory Sciences, College of Pharmacy, University of Basrah, Basrah, Iraq
}

\begin{abstract}
Starting with 4-aminoantipyrine compound (4-amino-1,5-dimethyl-2-phenyl-1,2-dihydro-3Hpyrazol-3-one), two $\mathrm{N}$-alkyl derivatives were synthesized (5) or (6) by reaction with chloroacetyl chloride or 3-chloropropionyl chloride, respectively. On the other hand, hydrazide compounds (thiophene2-carbohydrazide and benzocarbazide) were used to synthesize 1,3,4-oxadiazole and 1,2,4-triazole thiol derivatives (2a), (2b), (4a), and (4b), by cyclization reaction. Finally, six derivatives were synthesized (7a-10a) and (11b-12b) by nucleophilic substitution reaction of thiol moiety in (2a, 2b, $4 \mathbf{a}$ or $4 \mathbf{b})$ compounds with (5) or (6). The synthesized compounds were characterized using elemental microanalysis, IR, and ${ }^{1} \mathrm{H}-\mathrm{NMR}$ spectroscopy. The analgesic activity of the compounds was evaluated using the hot plate method and compared with paracetamol as a standard drug. Compounds (9a and 11b) gave potent activity ( 81 and $66 \%$, respectively) greater than other synthesized compounds, and compound (11b) has potent activity compared with paracetamol (73\%) as a standard drug. Whereas, other compounds $(\mathbf{6}, \mathbf{8 a}$, and 10a) showed moderate activity compared with the standard drug.
\end{abstract}

Keywords: 4-aminoantipyrine, pyrazolone, 1,3,4-oxadiazole, 1,2,4-triazole, analgesic evaluation, organic synthesis

\section{INTRODUCTION}

The creation of modified molecules compared to the original molecules and a study linking them with biological activity constitutes an important research project in the field of pharmaceutical preparations. The biological activity of the prepared or modified organic molecules from some medicines is characterized by its properties based on the chemical structure that leads to certain activities related to the original molecule and the other biological activity is related to the presence of the added organic compound. The process of modification in the original compound is done by treating the basic structure of the compound and this leads to the enhancement of the activity of the compound and also eliminates some problems in the treatment and some side effects such as toxicity and others (1). The fever and pain in the body are due to the mediators of inflammation, which are prostaglandins. Here comes the role of non-steroidal anti-inflammatory drugs (NSAIDs) that effectively block the synthesis of these mediators. The more effective the drug is, the less pain and time it takes to relieve this pain. This type of drug has been used in the past and present in the treatment of many inflammation-related diseases such as gout, asthma, arthritis, and cardiovascular diseases (2). The side effects of the drugs used in the market cause serious clinical problems. Among the most important drugs that have side effects are anti-inflammatory, analgesic, and antipyretic drugs. Hence, scientists began to develop these drugs to be more effective and with fewer side effects $(3,4)$.

Pyrazolone compounds have acquired a variety of importance in many pharmaceutical industries, due to the acquisition of this type of compounds in various biological uses such as sedative, muscle relaxant, antibiotic, anticonvulsant, antihypertensive, antidepressant activities. According to the chemical structure, pyrazolone is a five-membered lactam ring because it contains a ketone group and two nitrogen atoms. 4-Aminoantipyrine has been used since its preparation around 1880 as an antipyretic

* Corresponding author: e-mail: munther.ali@uobasrah.edu.iq, muntheralamery@yahoo.com 
and analgesic, and it is a compound with a relatively simple structure. This drug is enzymatically converted in the human body by the liver to be excreted with urine in the form of 4-hydroxyantipyrine. Scientists have added modifications to the drug to get rid of its side effects, such as agranulocytosis (5), as well as to improve its analgesic and antipyretic properties. Thus, many drug derivatives were prepared such as aminophenazone (aminopyrine or amidopyrine), propyphenazone, dipyrone (metamizole), and phenylbutazone $(6,7)$. Many derivatives were prepared from the compound 4-aminoantipyrine, these prepared compounds were used as antimicrobial (8-10), antifungal $(11,12)$, anti-inflammatory $(13,14)$, and many other activities $(15,16)$.

Due to the great importance of this type of pyrazolone compounds, we combined two types of aromatic rings, oxadiazole and triazole with this ring to study the effect of these aromatic rings on the original ring. New derivatives of 4-aminoantipyrine were prepared by reaction with chloroacetyl chloride or 3-chloropropionyl chloride. The latter two compounds were reacted with 5-(thiophen-2-yl)1,3,4-oxadiazole-2-thiol or 4-phenyl-5-(thiophen-2yl)-4H-1,2,4-triazole-3-thiol to give the final compounds. The synthesized compounds were identified by elemental analysis, FT-IR, and ${ }^{1} \mathrm{H}-\mathrm{NMR}$ spectra. Analgesic activity was used to evaluate the synthesized compounds by hot plate test compared with paracetamol drug.

\section{EXPERIMENTAL}

\section{Materials}

All the solvents and chemicals were from Sigma Aldrich, Thomas Baker, ALPHA (India), Sunway Pharm (China), Merck, and Fluka. The physical properties including the melting point of the synthesized compounds were determined by uncorrected Barnstead electrothermal apparatus in open capillaries. Thin layer analytical chromatography (TLC) on silica gel 60 F254 aluminum sheets $20 \times 20 \mathrm{~cm}$ (Merck) was used to monitor the reaction progress and test the purity of the synthesized compounds, using various ratios of eluent systems and observed under UV light $(\lambda=254)$. The compounds' ${ }^{1} \mathrm{H}-\mathrm{NMR}$ spectra were scanned on a $500 \mathrm{MHz}$ INOVA (Switzerland) spectrometer with tetramethylsilane (TMS) as an internal standard and dimethyl sulfoxide (DMSO- $\mathrm{d}_{6}$ ) as a solvent. All of the chemicals tested had their FT-IR spectra measured as $\mathrm{KBr}$ disks on an FT-IR 8400S SHIMADZU (Japan), in the Chemistry Department / College of Science / Basrah University. The elemental microanalysis $(\mathrm{CHN})$ for synthesized compounds was performed using CHN elemental analyzer flash EA 1112 series, (Thermo Finnigan).

\section{Synthesis of compounds \\ Synthesis of thiophene-2-carbohydrazide (1a) and benzohydrazide (1b)}

In a $100 \mathrm{~mL}$ round-bottomed flask, a mixture of $0.1 \mathrm{~mol}$ of ethyl 2-thiophenecarboxylate or ethyl benzoate and (3.242 mL, $0.2 \mathrm{~mol}$ ) $99 \%$ of hydrazine hydrate in $25 \mathrm{~mL}$ of absolute ethanol were refluxed for $6 \mathrm{~h}$. The excess of ethanol and hydrazine was evaporated under reduced pressure. The residue was filtered by Buchner funnel to form a solid powder, washed with water, dried at room temperature, and crystallized from methanol (17).

(1a): White crystals, $84 \%$ yield, m. p. 140$141^{\circ} \mathrm{C}$. IR $(\mathrm{KBr}): v\left(\mathrm{~cm}^{-1}\right)=3309,3198(\mathrm{~N}-\mathrm{H}), 3074$ (C-H, aromatic), $1624(\mathrm{C}=\mathrm{O}), 1543,1419(\mathrm{C}=\mathrm{C})$, 1327 (C-N).

(1b): White crystals, 90\% yield, m. p. 113$115^{\circ} \mathrm{C}$, IR $(\mathrm{KBr}): v\left(\mathrm{~cm}^{-1}\right)=3320,3178(\mathrm{~N}-\mathrm{H}), 3043$ (C-H, aromatic), $1612(\mathrm{C}=\mathrm{O}), 1537,1428(\mathrm{C}=\mathrm{C}), 1293$ (C-N).

\section{Synthesis of 5-(thiophen-2-yl)-1,3,4-oxadiazole- 2-thiol (2a) and 5-phenyl-1,3,4-oxadiazole-2- thiol (2b)}

A mixture of 0.1 mole of thiophene-2-carbohydrazide (1a) or benzohydrazide (1b) was added to a solution containing 95\% ethanol and $0.4 \mathrm{~g}, 0.1$ mole of sodium hydroxide (dissolved in the least quantity of water), followed by $0.9 \mathrm{~mL}, 0.15$ mole of carbon disulfide. The reaction mixture was heated under reflux for 3 hours until no more hydrogen sulfide was produced. The resultant mixture was diluted down and acidified with ice-cold diluted hydrochloric acid. After 30 minutes in an ice bath, the reaction mixture was filtered, washed with water, and recrystallized from ethanol $(18,19)$.

(2a): White crystals, 72\% yield, m. p. 199$201^{\circ} \mathrm{C}$. IR (KBr): $v\left(\mathrm{~cm}^{-1}\right)=3097(\mathrm{C}-\mathrm{H}$, aromatic), $2762(\mathrm{~S}-\mathrm{H}), 1612(\mathrm{C}=\mathrm{N}$, oxadiazole ring), 1510, 1419 $(\mathrm{C}=\mathrm{C}), 1280,1176$ (C-O-C). ${ }^{1} \mathrm{H}$ NMR (DMSO-d $)$ : $\delta(\mathrm{ppm})=7.96(\mathrm{dd}, 1 \mathrm{H}, J=7.96 \mathrm{~Hz}$, thiophene-Hc), 7.79 (dd, $1 \mathrm{H}, J=7.79 \mathrm{~Hz}$ thiophene-Ha), 7.28 (m, 1H, $J=7.28 \mathrm{~Hz}$ thiophene-Hb).

(2b): White crystals, 76\% yield, m. p. 237$239^{\circ} \mathrm{C}$. IR $(\mathrm{KBr}): v\left(\mathrm{~cm}^{-1}\right)=3063(\mathrm{C}-\mathrm{H}$, aromatic), $2804(\mathrm{~S}-\mathrm{H}), 1608(\mathrm{C}=\mathrm{N}$, oxadiazole ring), 1496, $1446(\mathrm{C}=\mathrm{C}), 1184,1068$ (C-O-C). ${ }^{1} \mathrm{H}$ NMR $\left(\mathrm{DMSO}_{6}\right): \delta(\mathrm{ppm})=7.90-7.88(\mathrm{~m}, 2 \mathrm{H}, J=7.89 \mathrm{~Hz}$, Ar-Hortho $)$ 7.66-7.58 (m, 3H, $J=7.61 \mathrm{~Hz}$, Ar-Hmeta,para). 


\section{Synthesis of 1,2,4-triazole \\ Synthesis of thiosemicarbazide (3a) and (3b)}

To a mixture of 0.1 mole thiophene-2-carbohydrazide (1a) or benzohydrazide (1b) in a cosolvent of dioxane : ethanol ( $4: 1), 1.19 \mathrm{~mL}, 0.1$ mole phenyl iso-thiocyanate was added at $60^{\circ} \mathrm{C}$. The reaction mixture was stirred at $60^{\circ} \mathrm{C}$ for $15 \mathrm{~min}$, and then at room temperature for $1 \mathrm{~h}$. The separated crystals were filtered, washed with cold ethanol, and dried at room temperature $(20,21)$. The products were used in the next step without further purification.

\section{Synthesis of 4-phenyl-5-(thiophen-2-yl)-4H- 1,2,4-triazole-3-thiol (4a) and 4,5-diphenyl-4H- 1,2,4-triazole-3-thiol (4b)}

In $50 \mathrm{~mL}$ of water, a solution of 0.05 mole thiosemicarbazide (3a) or (3b) and $0.2 \mathrm{~g}, 0.05$ mole sodium hydroxide was heated under reflux for 2 hours. The yellow solution was then filtered and acidified to $\mathrm{pH} 4$ with a cold solution of $2 \mathrm{M}$ hydrochloric acid. Separated crystals were filtered and washed in water $(20,21)$. The products were recrystallized from methanol and dried at room temperature.

(4a): White crystals, 68\% yield, m. p. 264$265^{\circ} \mathrm{C}$. IR (KBr): $v\left(\mathrm{~cm}^{-1}\right)=3106(\mathrm{C}-\mathrm{H}$, aromatic), $2742(\mathrm{~S}-\mathrm{H}), 1581(\mathrm{C}=\mathrm{N}$, triazole ring), 1504, 1435 $(\mathrm{C}=\mathrm{C}), 1315,1265$ (C-N-C). ${ }^{1} \mathrm{H}$ NMR (DMSO-d $\left.{ }_{6}\right): \delta$ $(\mathrm{ppm})=7.68(\mathrm{dd}, 1 \mathrm{H}$, thiophene-Hc), $6.99(\mathrm{dd}, 1 \mathrm{H}$, thiophene-Ha), $6.70(\mathrm{~m}, 1 \mathrm{H}$, thiophene-Hb), 7.62$7.45 \mathrm{ppm}$ (m, 5H, Ar-H-triazole attach).

(4b): White crystals, 70\% yield, m. p. 282$284^{\circ} \mathrm{C}$. IR (KBr): $v\left(\mathrm{~cm}^{-1}\right)=3105(\mathrm{C}-\mathrm{H}$, aromatic), $2746(\mathrm{~S}-\mathrm{H}), 1589(\mathrm{C}=\mathrm{N}$, triazole ring $), 1546,1504$ $(\mathrm{C}=\mathrm{C}), 1334,1273(\mathrm{C}-\mathrm{N}-\mathrm{C}) .{ }^{1} \mathrm{H}$ NMR (DMSO-d $\left.{ }_{6}\right): \delta$ $(\mathrm{ppm})=7.52-7.29(\mathrm{~m}, 10 \mathrm{H}, J=7.4 \mathrm{~Hz}, \mathrm{Ar}-\mathrm{H})$.

\section{Synthesis of 2-chloro-N-(1,5-dimethyl-3- oxo-2-phenyl-2,3-dihydro-1H-pyrazol-4-yl) acetamide (5) and 3-chloro-N-(1,5-dimethyl- 3-oxo-2-phenyl-2,3-dihydro-1H-pyrazol-4-yl) propenamide (6)}

In a $100 \mathrm{~mL}$ round-bottomed flask, $15 \mathrm{~mL}$ of chloroform, $2.03 \mathrm{~g}, 0.01$ mole of 4-aminoantipyrine, and $0.132 \mathrm{~g}, 0.01$ mole of anhydrous potassium carbonate were added. To this mixture, 0.01 mole of chloroacetyl chloride or 3-chloropropionyl chloride was added, respectively, drop-wise with stirring for $20 \mathrm{~min}$. The reaction mixture was refluxed on a water bath at $60^{\circ} \mathrm{C}$ for $3 \mathrm{~h}$. Chloroform was flushed to give a viscous solution which washed with $(5 \% \mathrm{w} / \mathrm{v}$, $35 \mathrm{~mL}$ ) aqueous solution of sodium bicarbonate, the precipitate formed was filtered and dried, then recrystallized with ethanol (22).
5: Pale yellow crystals, 55\% yield, m. p. 190$193^{\circ} \mathrm{C}$, IR (KBr): $v\left(\mathrm{~cm}^{-1}\right)=3190(\mathrm{~N}-\mathrm{H}), 3043(\mathrm{C}-\mathrm{H}$, aromatic), 2928, 2874 (C-H, aliphatic), 1693, 1639 $(\mathrm{C}=\mathrm{O}$, amide), 1558, $1489(\mathrm{C}=\mathrm{C}), 1315,1296(\mathrm{C}-\mathrm{N})$. ${ }^{1} \mathrm{H}$ NMR $\left(\right.$ DMSO-d $\left._{6}\right): \delta(\mathrm{ppm})=9.47(\mathrm{~s}, 1 \mathrm{H}, \mathrm{NH})$, 7.52-7.50 (m, 2H, $J=7.51 \mathrm{~Hz}$, Ar- $\left.\mathrm{H}_{\text {meta }}\right), 7.37-7.32(\mathrm{~m}$, $\left.3 \mathrm{H}, J=7.36 \mathrm{~Hz}, \mathrm{Ar}-\mathrm{H}_{\text {ortho, para }}\right), 4.24\left(\mathrm{~s}, 2 \mathrm{H}, \mathrm{CH}_{2}-\mathrm{Cl}\right)$, 3.06 (s, 3H, N-CH $), 2.13$ (s, 3H, C-CH $)$. Anal. Calc. (Found) for $\mathrm{C}_{13} \mathrm{H}_{14} \mathrm{ClN}_{3} \mathrm{O}_{2}$ (279.72): C, 55.82 (55.89), $\mathrm{H}, 5.04$ (5.17), N, 15.02 (14.66).

6: Pale yellow crystals, $80 \%$ yield, m. p. 210$211^{\circ} \mathrm{C}$, IR (KBr): $v\left(\mathrm{~cm}^{-1}\right)=3190(\mathrm{~N}-\mathrm{H}), 3009(\mathrm{C}-\mathrm{H}$, aromatic), 2889 (C-H, aliphatic), 1685, 1647 (C=O, amide), 1531, 1489 (C=C), 1315, 1199 (C-N). ${ }^{1} \mathrm{H}$ NMR $\left(\mathrm{DMSO}_{6}\right): \delta(\mathrm{ppm})=9.27(\mathrm{~s}, 1 \mathrm{H}, \mathrm{NH}), 7.53-7.49$ $\left(\mathrm{m}, 2 \mathrm{H}, J=7.51 \mathrm{~Hz}\right.$, Ar- $\left.\mathrm{H}_{\text {meta }}\right), 7.37-7.33(\mathrm{~m}, 3 \mathrm{H}$, $J=7.36 \mathrm{~Hz}$, Ar- $\left.\mathrm{H}_{\text {ortho, para }}\right), 3.86$ (t, $2 \mathrm{H}, J=6.2 \mathrm{~Hz}$, $\left.-\mathrm{CH}_{2}-\mathrm{Cl}\right), 2.73\left(\mathrm{t}, 2 \mathrm{H}, J=6.2 \mathrm{~Hz},-\mathrm{CH}_{2}-\right), 3.05(\mathrm{~s}, 3 \mathrm{H}$, $\left.\mathrm{N}-\mathrm{CH}_{3}\right), 2.13$ (s, 3H, C-CH $)$. Analysis: calcd (found) for $\mathrm{C}_{14} \mathrm{H}_{16} \mathrm{ClN}_{3} \mathrm{O}_{2}$ (293.75): C, 57.24 (57.62), H, 5.49 (5.13), N, 14.30 (14.70).

\section{General synthesis of final derivatives of aminoantipyrine (7a, 8a, 9a, and 10a)}

The compounds N-(1,5-dimethyl-3-oxo2-phenyl-2,3-dihydro-1H-pyrazol-4-yl)-2((5-(thiophen-2-yl)-1,3,4-oxadiazol-2-yl)thio) acetamide (7a), N-(1,5-dimethyl-3-oxo-2-phenyl2,3-dihydro-1H-pyrazol-4-yl)-2-((4-phenyl5-(thiophen-2-yl)-4H-1,2,4-triazol-3-yl)thio) acetamide (8a), N-(1,5-dimethyl-3-oxo-2-phenyl2,3-dihydro-1H-pyrazol-4-yl)-3-((5-(thiophen-2yl)-1,3,4-oxadiazol-2-yl)thio)propenamide (9a) and N-(1,5-dimethyl-3-oxo-2-phenyl-2,3-dihydro-1Hpyrazol-4-yl)-3-((4-phenyl-5-(thiophen-2-yl)-4H1,2,4-triazol-3-yl)thio)propenamide (10a) were synthesized by the same method $(23,24)$.

A mixture of 0.015 mole of (2a) or (4a), 0.018 mole of (5) or (6), and 0.02 mole of anhydrous sodium acetate in $50 \mathrm{~mL}$ of absolute ethanol was heated under reflux for $3 \mathrm{~h}$, then allowed to cool, and poured into $100 \mathrm{~mL}$ of cold-water containing ice. The solid product was collected and recrystallized from ethanol.

7a: White crystals, $74 \%$ yield, m. p. $218-219^{\circ} \mathrm{C}$, IR $(\mathrm{KBr}): v\left(\mathrm{~cm}^{-1}\right)=3174(\mathrm{~N}-\mathrm{H}), 3117(\mathrm{C}-\mathrm{H}$, aromatic), 2989, 2847 (C-H, aliphatic), 1685, $1643(\mathrm{C}=\mathrm{O}$, amide), $1589(\mathrm{C}=\mathrm{N})$, 1535, $1477(\mathrm{C}=\mathrm{C}), 1323,1172$ $(\mathrm{C}-\mathrm{O}, \mathrm{C}-\mathrm{N}) .{ }^{1} \mathrm{H}$ NMR $\left(\mathrm{DMSO}_{\mathrm{6}}\right): \delta(\mathrm{ppm})=9.51(\mathrm{~s}$, $1 \mathrm{H}, \mathrm{NH}), 7.95$ (dd, 1H, thiophene-Hc), $7.83(\mathrm{dd}, 1 \mathrm{H}$, thiophene-Ha), $7.29(\mathrm{~m}, 1 \mathrm{H}$, thiophene-Hb), 7.53$7.49\left(\mathrm{~m}, 2 \mathrm{H}, J=7.51 \mathrm{~Hz}, \mathrm{Ar}-\mathrm{H}_{\text {meta }}\right), 7.36-7.28(\mathrm{~m}, 3 \mathrm{H}$, $\left.J=7.35 \mathrm{~Hz}, \mathrm{Ar}-\mathrm{H}_{\text {ortho, para }}\right), 4.29\left(\mathrm{~s}, 2 \mathrm{H},-\mathrm{CH}_{2}-\right), 3.05$ (s, 3H, N-CH $\mathrm{CH}_{3}, 2.11\left(\mathrm{~s}, 3 \mathrm{H}, \mathrm{C}-\mathrm{CH}_{3}\right)$. Analysis: calcd 
(found) for $\mathrm{C}_{19} \mathrm{H}_{17} \mathrm{~N}_{5} \mathrm{O}_{3} \mathrm{~S}_{2}$ (427.50): C, 53.38 (53.49), H, 4.01 (3.96), N, 16.38 (15.95).

8a: White crystal, $66 \%$ yield, m. p. $220-222^{\circ} \mathrm{C}$, IR $(\mathrm{KBr}): v\left(\mathrm{~cm}^{-1}\right)=3178(\mathrm{~N}-\mathrm{H}), 3043(\mathrm{C}-\mathrm{H}$, aromatic), 2928 (C-H, aliphatic), 1678, $1639(\mathrm{C}=\mathrm{O}$, amide), $1581(\mathrm{C}=\mathrm{N}), 1538,1492(\mathrm{C}=\mathrm{C}), 1311,1192(\mathrm{C}-\mathrm{N}) .{ }^{1} \mathrm{H}$ NMR $\left(\mathrm{DMSO}-\mathrm{d}_{6}\right): \delta(\mathrm{ppm})=9.52(\mathrm{~s}, 1 \mathrm{H}, \mathrm{NH}), 7.68-$ $7.55(\mathrm{~m}, 5 \mathrm{H}, \mathrm{Ar}-\mathrm{H}$ triazole attach and $1 \mathrm{H}$, thiophene$\mathrm{Hc}), 6.72$ (dd, 1H, thiophene-Ha), 7.00 (m, 1H, thiophene-Hb), 7.52-7.31 (m, 5H, Ar-H pyrazole attach), 4.11 (s, 2H, $\left.-\mathrm{CH}_{2}-\right), 3.05$ (s, 3H, N-CH $), 2.12$ (s, 3H, C- $\mathrm{CH}_{3}$ ). Analysis: calcd (found) for $\mathrm{C}_{25} \mathrm{H}_{22} \mathrm{~N}_{6} \mathrm{O}_{2} \mathrm{~S}_{2}$ (502.61): C, 59.74 (58.78), H, 4.41 (4.24), N, 16.72 (16.45).

9a: White crystals, $78 \%$ yield, m. p. $193-195^{\circ} \mathrm{C}$, IR $(\mathrm{KBr}): v\left(\mathrm{~cm}^{-1}\right)=3178(\mathrm{~N}-\mathrm{H}), 3036(\mathrm{C}-\mathrm{H}$, aromatic), 2924 (C-H, aliphatic), 1681, $1647(\mathrm{C}=\mathrm{O}$, amide), $1589(\mathrm{C}=\mathrm{N}), 1543,1473(\mathrm{C}=\mathrm{C}), 1303,1238,1176(\mathrm{C}-$ $\mathrm{O}, \mathrm{C}-\mathrm{N}) .{ }^{1} \mathrm{H}$ NMR $\left(\mathrm{DMSO}_{6}\right): \delta(\mathrm{ppm})=9.27(\mathrm{~s}$, $1 \mathrm{H}, \mathrm{NH}), 7.955$ (dd, $1 \mathrm{H}$, thiophene-Hc), 7.83 (dd, $1 \mathrm{H}$, thiophene-Ha), 7.29 ( $\mathrm{m}, 1 \mathrm{H}$, thiophene-Hb), 7.52-7.32 (m, 5H, Ar-H pyrazole attach), $3.52(\mathrm{t}, 2 \mathrm{H}, J=6.7 \mathrm{~Hz}$, $\left.-\mathrm{CH}_{2}-\mathrm{S}-\right), 2.89$ (t, 2H, J=6.7 Hz, - $\left.\mathrm{CH}_{2}-\right), 3.05$ (s, 3H, $\left.\mathrm{N}-\mathrm{CH}_{3}\right), 2.13$ (s, 3H, C-CH $\mathrm{CH}_{3}$. Analysis: calcd (found) for $\mathrm{C}_{20} \mathrm{H}_{19} \mathrm{~N}_{5} \mathrm{O}_{3} \mathrm{~S}_{2}$ (441.52): C, 54.41 (54.00), H, 4.34 (4.24), N, 15.86 (15.57).

10a: White crystals, $78 \%$ yield, m. p. $202-204^{\circ} \mathrm{C}$, IR $(\mathrm{KBr}): v\left(\mathrm{~cm}^{-1}\right)=3155(\mathrm{~N}-\mathrm{H}), 3055(\mathrm{C}-\mathrm{H}$, aromatic), 2916 (C-H, aliphatic), 1674, $1647(\mathrm{C}=\mathrm{O}$, amide), $1581(\mathrm{C}=\mathrm{N}), 1496,1435(\mathrm{C}=\mathrm{C}), 1315,1236(\mathrm{C}-\mathrm{N})$. Analysis: calcd (found) for $\mathrm{C}_{26} \mathrm{H}_{24} \mathrm{~N}_{6} \mathrm{O}_{2} \mathrm{~S}_{2}$ (516.64): $\mathrm{C}$, 60.45 (60.05), H, 4.68 (4.46), N, 16.27 (16.14).

\section{General synthesis of final derivatives of aminoantipyrine, $N$-(1,5-dimethyl-3-oxo-2- phenyl-2,3-dihydro-1H-pyrazol-4-yl)-2-((4,5- diphenyl-4H-1,2,4-triazol-3-yl)thio)acetamide (11b) and N-(1,5-dimethyl-3-oxo-2-phenyl-2,3- dihydro-1H-pyrazol-4-yl)-3-((5-phenyl-1,3,4- oxadiazol-2-yl)thio)propanamide (12b)}

A mixture of 0.015 mole of (2b) and 0.018 mole of (6) or 0.015 mole of (4b) and 0.018 mole of (5), each one with 0.02 mole of anhydrous sodium acetate in $50 \mathrm{~mL}$ of absolute ethanol was heated under reflux for $3 \mathrm{~h}$, then allowed to cool, and poured into $100 \mathrm{~mL}$ of cold-water containing ice. The solid product was collected and recrystallized from ethanol $(23,24)$.

11b: White crystal, $72 \%$ yield, m. p. $242-243^{\circ} \mathrm{C}$, IR $(\mathrm{KBr}): v\left(\mathrm{~cm}^{-1}\right)=3167(\mathrm{~N}-\mathrm{H}), 3021(\mathrm{C}-\mathrm{H}$, aromatic), 2935 (C-H, aliphatic), 1670, $1631(\mathrm{C}=\mathrm{O}$, amide), $1576(\mathrm{C}=\mathrm{N}), 1524,1490(\mathrm{C}=\mathrm{C}), 1302,1188(\mathrm{C}-\mathrm{N})$. ${ }^{1} \mathrm{H}$ NMR $($ DMSO-d $): \delta(\mathrm{ppm})=9.50(\mathrm{~s}, 1 \mathrm{H}, \mathrm{NH})$, 7.59-7.31 (m, 15H, Ar-H), 4.15 (s, 2H, - $\left.\mathrm{CH}_{2}-\mathrm{S}-\right), 3.05$ (s, 3H, N-CH $), 2.12\left(\mathrm{~s}, 3 \mathrm{H}, \mathrm{C}-\mathrm{CH}_{3}\right)$. Analysis: calcd (found) for $\mathrm{C}_{27} \mathrm{H}_{24} \mathrm{~N}_{6} \mathrm{O}_{2} \mathrm{~S}$ (496.59): C, 65.30 (65.86), H, 4.87 (4.86), N, 16.92 (16.16).

12b: White crystal, $78 \%$ yield, m. p. $186-188^{\circ} \mathrm{C}$, IR $(\mathrm{KBr}): v\left(\mathrm{~cm}^{-1}\right)=3194(\mathrm{~N}-\mathrm{H}), 3020(\mathrm{C}-\mathrm{H}$, aromatic), 2924 (C-H, aliphatic), 1693, 1651 (C=O, amide), $1616(\mathrm{C}=\mathrm{N})$, 1593, $1527(\mathrm{C}=\mathrm{C})$, 1292, $1195(\mathrm{C}-\mathrm{N})$. ${ }^{1} \mathrm{H}$ NMR $\left(\mathrm{DMSO}-\mathrm{d}_{6}\right): \delta(\mathrm{ppm})=9.27(\mathrm{~s}, 1 \mathrm{H}, \mathrm{NH})$, 8.01-7.99 (m, $2 \mathrm{H}, J=8.00 \mathrm{~Hz}$, Ar- $\mathrm{H}_{\text {ortho }}$, attached to oxadiazole), 7.65-7.59 (m, 3H, $J=7.61 \mathrm{~Hz}$, Ar$\mathrm{H}_{\text {meta, para }}$, attached to oxadiazole), 7.52-7.49 (m, 2H, $J=7.50 \mathrm{~Hz}$, Ar- $\mathrm{H}_{\text {meta }}$ pyrazole attach), 7.37-7.31 (m, $3 \mathrm{H}, J=7.34 \mathrm{~Hz}, \mathrm{Ar}-\mathrm{H}_{\text {ortho, para }}$, pyrazole attach), 3.55 (t, $2 \mathrm{H}, J=6.7 \mathrm{~Hz},-\mathrm{CH}_{2}-\mathrm{S}-$ ), 2.91 (t, $2 \mathrm{H}, J=6.7 \mathrm{~Hz}$, $\left.-\mathrm{CH}_{2}{ }^{-}\right), 3.05$ (s, 3H, N-CH $), 2.14\left(\mathrm{~s}, 3 \mathrm{H}, \mathrm{C}-\mathrm{CH}_{3}\right)$. Analysis: calcd (found) for $\mathrm{C}_{27} \mathrm{H}_{24} \mathrm{~N}_{6} \mathrm{O}_{2} \mathrm{~S}$ (435.50): $\mathrm{C}$, 60.68 (59.99), H, 4.86 (4.79), N, 16.08 (15.90).

\section{Evaluation of analgesic activity using hot plate test}

In this experiment, fourteen groups of Swiss albino mice of both genders were used, each with six individuals. The overnight fasting mice were given the following treatment: Mice in Group 1 were given $10 \mathrm{~mL} / \mathrm{kg}$ of vehicle (olive oil) as a control group, and mice in Group 2 were given $10 \mathrm{mg} / \mathrm{kg}$ of paracetamol as a standard group, while mice in Groups 3-14 were given $10 \mathrm{mg} / \mathrm{kg}$ of investigated substances orally. Mice were placed within a glass cylinder placed on a well-regulated hot plate maintained at $55 \pm 1^{\circ} \mathrm{C}$ after one hour of all oral treatments, and the difference time between placing mice on the surface of the hot plate and the occurrence of fore hind paws licking or jumping was recorded as reaction time. It was decided that the cutoff duration should not exceed 20 seconds maximum delay in order to minimize paw injury $(25,26)$.

\section{RESULTS AND DISCUSSION}

\section{Chemistry}

Treatment of ethyl 2-thiophenecarboxylate with hydrazine hydrate in refluxed absolute ethanol gave thiophene-2-carbohydrazide (1a) which showed significant IR absorption bands at $v 3309$ and $3198 \mathrm{~cm}^{-1}$ due to $-\mathrm{NHNH}_{2}$ and $1624 \mathrm{~cm}^{-1}$ for $\mathrm{C}=\mathrm{O}$ amide (26). Same method, benzohydrazide (1b) could be synthesized and the product was characterized by the formation of $-\mathrm{NHNH}_{2}$ and $\mathrm{C}=\mathrm{O}$ of amide at $v 3320,3128 \mathrm{~cm}^{-1}$, and $1612 \mathrm{~cm}^{-1}$, respectively. However, refluxing of (1a) or (1) with carbon disulfide in the presence of an alkaline medium of ethanol gave white crystal of oxadiazole compound (2a) or (2b), respectively (27). On the other hand, the reaction of hydrazide compounds (1a) or (1b) 

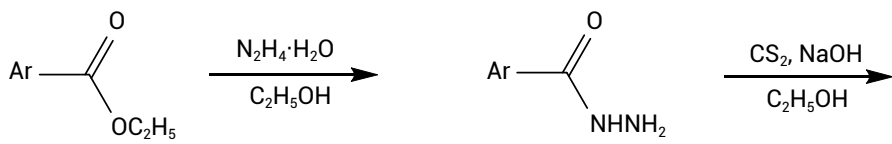<smiles>[Al]c1nnc(S)o1</smiles>

$(2 a, 2 b)$<smiles>Cc1ccccc1</smiles><smiles>O=C([AlH2])NNC(=S)Cc1ccccc1</smiles>

$(3 a, 3 b)$<smiles>Sc1nnc(Br)n1-c1ccccc1</smiles>

$(4 a, 4 b)$ with phenyl isothiocyanate in dioxane : ehanol as cosolvent gave intermediate isolated thiosemicarbazide compound (3a) or (3b), which was subjected to cyclization by aqueous alkaline medium to yield triazole compound (4a) or (4b) (28), as shown in Figure 1.

IR spectrum of oxadiazole and triazole compounds (2a), (2b), (4a), and (4b) exhibited new absorption bands at about $v 2700 \mathrm{~cm}^{-1}$ belonging to the $\mathrm{S}-\mathrm{H}$ bond and absence of the absorption bands of the amide group $(28,29)$. The ${ }^{1} \mathrm{H}-\mathrm{NMR}$ spectrum of (2a) gave three signals for three protons of thiophene, $\delta$ 7.965, 7.795, and 7.28 ppm for H-c, H-a, and H-b, respectively with $J$ coupling about $7 \mathrm{~Hz}$. Whereas, ${ }^{1} \mathrm{H}$ NMR of (2b) showed two multiplied signals for aromatic protons of phenyl ring, $\delta 7.90-7.88 \mathrm{ppm}$ attributed to two protons at ortho position with $J$ coupling of $7.89 \mathrm{~Hz}$ and $\delta$ 7.66-7.58 ppm referred to three protons at meta and para position with $J$ coupling of $7.61 \mathrm{~Hz}$. The signal of SH was lacking in the spectra of these four compounds because of proton fast exchange with solvent (30), as shown in Figure 2.

Another type of compounds was synthesized by refluxing of 4-aminoantipyrine with chloroacetyl chloride or 3-chloropropionyl chloride in chloroform solvent to give the compounds (5) or (6), respectively. The N-chloroacetylation of the amine group was performed in the presence of anhydrous potassium carbonate to remove the byproduct $\mathrm{HCl}$. The pale-yellow crystals of the products were crystalized from absolute ethanol to give pure compounds with good yield, as shown in Figure 3. The IR spectra of (5) and (6) showed medium absorption bands at $v$ $2190 \mathrm{~cm}^{-1}$ referred to stretching vibration of $\mathrm{N}-\mathrm{H}$, and strong bands at the range $v 1693-1639 \mathrm{~cm}^{-1}$ attributed to stretching vibration of $\mathrm{C}=\mathrm{O}$ (amide). The ${ }^{1} \mathrm{H}-\mathrm{NMR}$ spectra of these compounds gave download singlet signals at $\delta 9.47$ and 9.27 ppm for $\mathrm{NH}$ proton of compounds 5 and $\mathbf{6}$, respectively. Aromatic protons gave two multiplet signals at the range $\delta$ 7.52$7.31 \mathrm{ppm}$, the first signal at 7.52-7.50 ppm for two meta protons of phenyl group with $J$ coupling of $7.51 \mathrm{~Hz}$ and the second signal referred to three protons at ortho and meta position with $J$ coupling of $7.36 \mathrm{~Hz}$, whereas, aliphatic protons as singlet signals at $\delta 3.06$ and $2.13 \mathrm{ppm}$ for three protons of $\mathrm{CH}_{3}-\mathrm{N}$ and $\mathrm{CH}_{3}-\mathrm{C}$ groups. The clear difference between the two compounds was in the protons of methylene and ethylene bridge, where compound 5 gave singlet signal at $\delta 4.24 \mathrm{ppm}$ of $-\mathrm{CH}_{2}-$ whereas triplet signals were seen at $\delta 3.86$ and $2.73 \mathrm{ppm}$ for $-\mathrm{CH}_{2} \mathrm{CH}_{2}-\mathrm{Cl}$ with $J$ coupling $6.2 \mathrm{~Hz}$ of compound 6 . The purity of the compounds tested by elemental microanalysis showed good agreement between experimental and calculated values.<smiles>Cc1ccc(-c2nnc(S)n2-c2ccccc2)s1</smiles>

Figure 2. Chemical structure of 5-(thiophen-2-yl)-1,3,4-oxadiazole-2-thiol (2a) and 4-phenyl-5-(thiophen-2-yl)-4H-1,2,4-triazole-3-thiol (4a). 
<smiles>Cc1c(N)c(=O)n(-c2ccccc2)n1C</smiles>

Figure 3. Synthesis of compounds (5) and (6).

Because of the large size of a sulfur atom, by using a base as a catalyst (anhydrous sodium acetate), the negative charge of the thiolate ion is spread over a larger volume of space that makes thiolate ion a stable and good nucleophile. Therefore, compounds $\mathbf{2 a}, \mathbf{2 b}, \mathbf{4 a}$, and $\mathbf{4 b}$ can easily attack as thiolate ion in the protic solvent (ethanol) the carbon atom adjacent to chloride atom in compounds $\mathbf{5}$ and $\mathbf{6}$ to form the compounds 7a, 8a, 9a, 10a, 11b, and 12b according to $S_{N} 2$ mechanism $(31,32)$, as shown in Figure 4.

The IR spectra of these compounds showed medium absorption bands at $v$ 3178-3155 and $1685-1639 \mathrm{~cm}^{-1}$ attributed to the stretching vibration of $\mathrm{N}-\mathrm{H}$ bond and $\mathrm{C}=\mathrm{O}$, respectively of the amide group (33). Another significant evidence the formation of the product was the absence of S-H band in these compounds about $v 2700 \mathrm{~cm}^{-1}$ which was at the compounds 2a, 2b, 4a, and $\mathbf{4 b}$ (34). The ${ }^{1} \mathrm{H}-\mathrm{NMR}$ spectra clearly showed a singlet signal at $\delta$ about 9 ppm due to one proton of $\mathrm{NH}$ group of amide fragment.

Aromatic protons gave similar multiplet signals at the range $\delta 7.53-7.31 \mathrm{ppm}$ attributed to five protons of phenyl attached to a nitrogen atom of the pyrazole ring. Compounds 7a and 9a gave matching three signals at $\delta 7.95,7.83$, and 7.29 ppm referred to three protons $\mathrm{Hc}, \mathrm{Ha}$, and $\mathrm{Hb}$, respectively with $J$ coupling about $7 \mathrm{~Hz}$ of thiophene ring, whereas, compound 8a another aromatic signal at $\delta 6.72$ and $7.00 \mathrm{ppm}$ due to two protons $\mathrm{Hc}$ and $\mathrm{Ha}$ of thiophene<smiles>Cc1c(NC(=O)CCC(C)(C)Cl)c(=O)n(-c2ccccc2)n1C</smiles>

protons, respectively. The third signal of thiophene proton $(\mathrm{Hb})$ was overlapped with the multiplet signals of phenyl proton attached to nitrogen of triazole ring at the range $\delta$ 7.68-7.55 ppm (six protons).

At the high field range, compound $7 \mathbf{a}$ gave absorption singlet signals at $\delta 4.29,3.05$, and $2.11 \mathrm{ppm}$, also, compound 8a showed the same signals at $\delta 4.11$, 3.05 and $2.12 \mathrm{ppm}$ conforming to the protons of the following groups, $-\mathrm{CH}_{2}-\mathrm{S}-, \mathrm{CH}_{3}-\mathrm{N}, \mathrm{CH}_{3}-\mathrm{C}$, respectively. At the same time, compound 9a gave two triplet signals at $\delta 3.52$ and $2.89 \mathrm{ppm}$ attributed to the protons of bridge fragment $-\mathrm{CH}_{2} \mathrm{CH}_{2}-\mathrm{S}$ - with $J$ coupling $6.7 \mathrm{~Hz}$, another singlet signals referred to the protons of the group $\mathrm{CH}_{3}-\mathrm{N}$ and $\mathrm{CH}_{3}-\mathrm{C}$ appeared at $\delta 3.05$ and 2.13 ppm, respectively.

For the ${ }^{1} \mathrm{H}$ NMR spectrum of compound (11b), it is difficult to distinguish between the protons for three types of aromatic systems, and this compound gave multiple signals at a narrow range of 7.59-7.31 ppm. Other types of signals appeared as a singlet at 4.15 , 3.05 , and $2.12 \mathrm{ppm}$ attributed to two protons of a methylene group, three protons of a methyl group attached to $\mathrm{N}$ atom, and three protons of methyl group attached to $\mathrm{C}$ atom of pyrazolone ring, respectively.

${ }^{1} \mathrm{H}$ NMR spectrum for (12b) showed four types of multiple signals for protons of aromatic systems, the first two signals at 8.01-7.99 ppm and 7.65-7.59 ppm attributed to two ortho protons and three meta-para protons of phenyl ring attached<smiles>Cc1c(NC(=O)CC(Cl)Cl)c(=O)n(-c2ccccc2)n1C</smiles><smiles>Cc1ccccc1</smiles>
$=\mathrm{N}-\mathrm{Ph} \quad\left(4^{\mathrm{a}}\right)$ $=0, \quad(2 \mathrm{~b})$ $=\mathrm{N}-\mathrm{Ph} \quad(4 \mathrm{~b})$

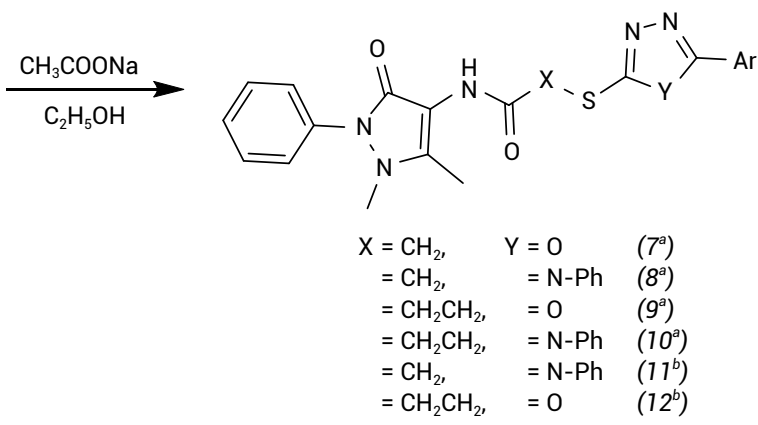


to oxadiazole ring, respectively. The second group of signals referred to five protons of phenyl attached to pyrazolone ring at the range 7.52-7.49 ppm for two protons at meta position with $J$ coupling $7.50 \mathrm{~Hz}$ and at 7.37-7.31 ppm for three protons at ortho-para position with $J$ coupling $7.34 \mathrm{~Hz}$.

\section{Analgesic activity}

The analgesic activity of the synthesized compounds was evaluated in mice using the analgesy - writhing test method using paracetamol as a standard

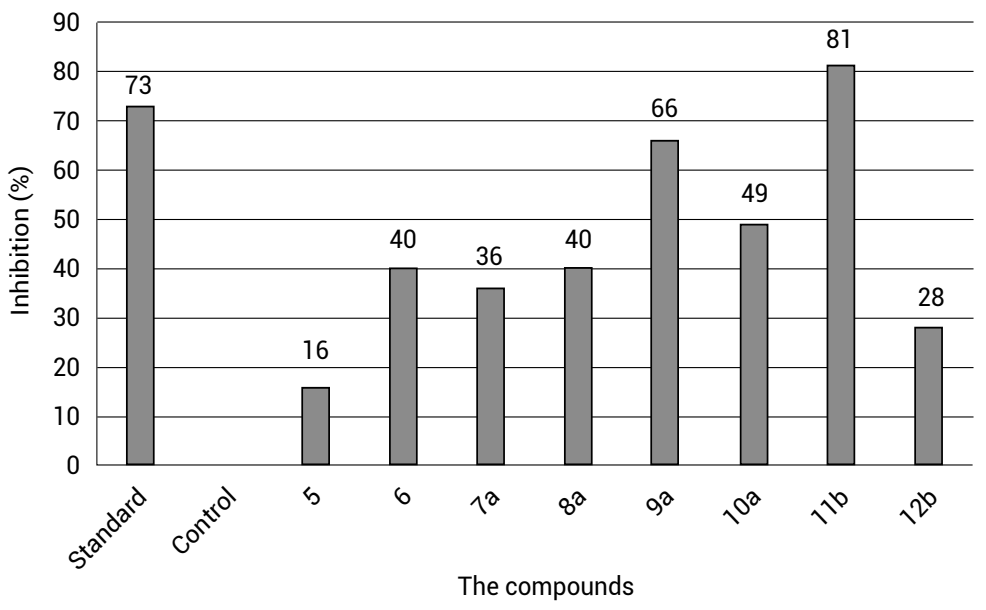

Figure 5 . Analgesic activity inhibition $\%$ by the hot plate method. drug. Table 1 shows the reaction time and inhibition $\%$ of the synthesized compounds and standard drug. The results showed that compounds 9a, 10a, and $11 \mathrm{~b}$ gave the best activity $(66 \%, 49 \%$, and $81 \%$, respectively) compared with other compounds, and compound 11b gave potent activity greater than the standard drug which may have a promising activity. On the other hand, the synthesized compounds $7 \mathbf{a}$ and $8 \mathbf{a}$ gave moderate activity (36\% and $40 \%$, respectively) as compared with the standard drug, as shown in Figure 5. The differences in the activity between compounds $7 \mathbf{a}$ and $\mathbf{8 a}$ (oxadiazole) with 9a, 10a, and 11b (triazole) may be attributed to the differences in the chemical structure between the two types of compounds. It was observed that the presence of the compound fragment that contains the heterocyclic rings (oxadiazole and triazole) in compounds (7a, 8a, 9a, 10a, and 11b) gave better activity than the compounds derived from them (compound $\mathbf{5}$ and 6), which may be attributed to the presence of the 1,3,4-oxadiazole and 1,2,4-triazole rings that affects the physicochemical and pharmacokinetic properties of the entire compound $(35,36)$.

\section{CONCLUSION}

We have described the synthesis of novel compounds derived from 4-aminoantipyrine by S-alkylation of some oxadiazole and triazole thiols as nucleophiles with $\mathrm{N}$-alkyl derivatives of 4-aminoantipyrine. All synthesized compounds were characterized on the basis of melting point, elemental analysis, FTIR, and NMR spectroscopy. The analgesic evaluation was tested for the synthesized compounds using the hot plate method by Swiss albino mice groups. Some of the final compounds gave promise to moderate analgesic activity and the inhibition $\%$ was in the range (36-81\%) as compared with paracetamol drug (73\%).

Table 1. Evaluation of analgesic activity by the hot plate method.

\begin{tabular}{|c|c|c|}
\hline Group & Reaction Time (Seconds) & Inhibition (\%) \\
\hline Standard & $13.41 \pm 1.84^{* * *}$ & 73 \\
\hline Control & $3.62 \pm 0.74$ & 16 \\
\hline 5 & $4.35 \pm 0.95$ & 40 \\
\hline 6 & $6.08 \pm 1.02^{*}$ & 36 \\
\hline $7 \mathrm{a}$ & $5.64 \pm 1.02$ & 40 \\
\hline $8 \mathrm{a}$ & $6.24 \pm 0.47^{*}$ & 66 \\
\hline $9 \mathrm{a}$ & $10.61 \pm 1.05^{* *}$ & 49 \\
\hline $10 \mathrm{a}$ & $7.22 \pm 0.93^{* *}$ & 81 \\
\hline $11 \mathrm{~b}$ & $18.51 \pm 2.15^{* * *}$ & 28 \\
\hline $12 \mathrm{~b}$ & $5.17 \pm 0.48$ & \\
\hline
\end{tabular}

Each value is the mean \pm S.D. for six mice, ${ }^{*} \mathrm{p}<0.05,{ }^{* *} \mathrm{p}<0.01, * * * \mathrm{p}<0.001$ compared with normal control. Data analyzed by using one-way ANOVA followed by T-test. 


\section{Conflict of interest}

The authors declare no conflicts of interest.

\section{REFERENCES}

1. Arora R., Sharma R., Tageza A., Grewal A., Saini B., Arora S.: J. Appl. Pharm. Sci. 11, 48 (2021).

2. Abdulkhaleq L., Assi M., Abdullah R., ZamriSaad M., Taufiq-Yap Y., Hezmee M.: Vet. World 11, 627 (2018).

3. Nunes C dos R., Barreto Arantes M., Menezes de Faria Pereira S., Leandro da Cruz L., de Souza Passos M., Pereira de Moraes L.: Molecules 25, 3726 (2020).

4. Mohanram I., Meshram J.: Int. Sch. Res. Notices 2014, 7 pages (2014).

5. Collares E., Troncon L.: Braz. J. Med. Biol. Res. 52 (2019).

6. Ibrahim H., Hamdy A., Merey H., Saad A.: J. Chromatogr. Sci. 59, 140 (2021).

7. Habekost A.: World J. Chem. Educ. 6, 134 (2018).

8. Teran R., Guevara R., Mora J., Dobronski L., Barreiro-Costa O., Beske T.: Molecules 24, 2696 (2019).

9. Bayeh Y., Mohammed F., Gebrezgiabher M., Elemo F., Getachew M., Thomas M.: Adv. Biol. Chem. 10, 127 (2020).

10. Tyagi M., Chandra S., Tyagi P., Akhtar J., Kandan A., Singh B.: J. Taibah Univ. Sci. 11, 110 (2017).

11. Maihub A., Sofian S., Awin A., Belaid A., Bensaber S., Hermann A: J. Pharmacol. Clin. Trials 2018, 55 (2018).

12. Yasar Q., Zaheer Z.: Int. J. Pharm. Investig. 11, 14 (2021).

13. Refat M., Hamza R., Adam A., Saad H., Gobouri A., Al-Salmi F.: Hum. Exp. Toxicol. 40, 325 (2021).

14. Chellaian J.: J. Heterocycl. Chem. 58, 928 (2021).

15. Mandewale M., Thorat B., Nivid Y., Jadhav R., Nagarsekar A., Yamgar R.: J. Saudi Chem. Soc. 22, 218 (2018).

16. Chaaban I., El Sayeda M., Mahran M., Abd El Razik H., El Salamouni N.: J. Saudi Chem. Soc. 20, 547 (2016).
17. Abdelrehim E.: ACS Omega 6, 1687 (2021).

18. Kumari M., Tahlan S., Narasimhan B., Ramasamy K., Lim S., et al.: BMC Chem. 15, 30 pages (2021).

19. Othman A., Kihel M., Amara S.: Arab. J. Chem. 12, 1660 (2019).

20. Aouad M., Messali M., Rezki N., Ali A., Lesimple A.: Acta Pharm. 65, 117 (2015).

21. Zaki R., El-Dean A., Radwan S., Saber A.: Heterocycl. Commun. 25, 39 (2019).

22. Lelyukh M., Martynets M., Kalytovska M., Drapak I., Harkov S., et al.: J. Appl. Pharm. Sci. 10, 151 (2020).

23. Dorababu A.: Heliyon 6, 169 pages (2020).

24. Bakr R.: Nymphaea alba and Liver Protection. In Dietary Interventions in Liver Disease. pp. 135-43, Academic Press, Elsevier 2019.

25. Lin Y-J., Xu Y., Xu J.: Evid. Based Complement. Alternat. Med. (Hindawi). 2018, 4 pages (2018).

26. Pitchaimani J., Raja M., Sujatha S., Mahapatra S., Moon D., et al.: RSC Adv. 6, 90982 (2016).

27. Abbasi M., Akhtar A., Nafeesa K., Siddiqui S., Khan K., et al.: J. Chil. Chem. Soc. 58, 2186 (2013).

28. Aly A., Hassan A., Makhlouf M., Bräse S.: Molecules 25, 3036 (2020).

29. Gökce H., Öztürk N., Ceylan Ü., Alpaslan Y., Alpaslan G.: Spectrochim. Acta A Mol. Biomol. Spectrosc. 163, 170 (2016).

30. Li Y., Liu Y., Wang H., Xiong X., Wei P., et al.: Molecules 18, 877 (2013).

31. Abu $\square$ Hashem A.: J. Heterocycl. Chem. 58, 74 (2021).

32. Dörwald F.: Side reactions in Organic Synthesis: a guide to successful synthesis design. John Wiley \& Sons, New York 2006.

33. Premnath D., Selvakumar P., Ravichandiran P., Selvan G., Indiraleka M., et al.: Spectrochim. Acta A Mol. Biomol. Spectrosc. 153, 118 (2016).

34. Chinyere E., Ukoha P., Agbo J., Obasi L.: Niger. J. Chem. Res. 23, 71 (2018).

35. Glomb T., Świątek P.: Int. J. Mol. Sci. 22, 64 pages (2021).

36. Kumar S., Khokra S., Yadav A.: Futur. J. Pharm. Sci. 7, 106 pages (2021). 